\title{
Gefarnate stimulates mucin-like glycoprotein secretion in conjunctival tissue and ameliorates corneal epithelial damage in animal dry-eye models
}

\author{
This article was published in the following Dove Press journal: \\ Clinical Ophthalmology \\ 25 January 2013 \\ Number of times this article has been viewed
}

\author{
Atsuyoshi Dota \\ Yuko Takaoka-Shichijo \\ Masatsugu Nakamura \\ Ophthalmic Research and \\ Development Center, Santen \\ Pharmaceutical Co, Ltd, Ikoma-shi, \\ Nara, Japan
}

Correspondence: Atsuyoshi Dota

Ophthalmic Research and

Development Center, Santen

Pharmaceutical Co, Ltd, 8916-16

Takayama-cho, Ikoma-shi, Nara

630-0101, Japan

Tel +81743794525

Fax +8I 7437945 I

Email atsuyoshi.dota@santen.co.jp
Purpose: The aim of this study was to evaluate the effect of gefarnate on mucin-like glycoprotein secretion in isolated rabbit conjunctival tissue, and on corneal epithelial damage in rabbit and cat dry-eye models.

Methods: Conjunctival tissue isolated from rabbits was treated with gefarnate. Mucin-like glycoprotein was detected in the culture supernatant by an enzyme-linked lectin assay. Gefarnate ointment was topically applied to eyes once daily for 7 days in the rabbit dry-eye model, in which the lacrimal glands, Harderian gland, and nictitating membrane were removed, or for 4 weeks in the cat dry-eye model, in which the lacrimal gland and nictitating membrane were removed. Corneal epithelial damage was evaluated by measurement of corneal permeability by rose bengal in the rabbit model or by fluorescein staining in the cat model.

Results: Gefarnate stimulated mucin-like glycoprotein secretion in conjunctival tissue in a dose-dependent manner. In the rabbit dry-eye model, application of gefarnate ointment to the eyes resulted in a dose-dependent decrease in rose bengal permeability in the cornea, with the effect being significant at concentrations of $\geq 0.3 \%$. In the cat dry-eye model, application of gefarnate ointment resulted in a significant decrease in the corneal fluorescein staining score.

Conclusion: These results suggest that gefarnate stimulates in vitro secretion of mucin-like glycoprotein in conjunctival tissue and ameliorates corneal epithelial damage in animal dry-eye models. Gefarnate may therefore be effective for treating dry eye.

Keywords: gefarnate, fluorescein staining, rose bengal permeability, rabbit, cat, dry eye

\section{Introduction}

Tear film consists of the following three layers: an outer lipid layer, an intermediate water layer, and an inner mucin layer. ${ }^{1}$ The inner mucin layer is derived from the goblet cells in the conjunctiva, and from the epithelial cells from cornea and conjunctiva as well as lacrimal glands. ${ }^{2}$ By reducing the surface tension of the tear on the hydrophobic corneal and conjunctival epithelium, mucins facilitate tear spread over the ocular surface. ${ }^{3}$ Mucins are able to retain water because of their hydrophilic character and provide a barrier to pathogens on the ocular surface. ${ }^{4}$ According to the definition provided by the Dry Eye Workshop, ${ }^{5}$ dry eye is a multifactorial disease of the tears and ocular surface that results in symptoms of discomfort, visual disturbance, and tear film instability with potential damage to the ocular surface. It is accompanied by increased osmolarity of the tear film and inflammation of the ocular surface. It is believed that quantitative or qualitative disturbances in the three layers of tear film cause dry eye. It has long been known 
that a decrease in the density of mucin-producing goblet cells in the conjunctival epithelium is a common characteristic of dry eye. ${ }^{6}$ Moreover, the percentage of MUC5AC-positive conjunctival cells is significantly decreased in patients with dry eye, ${ }^{7}$ whereas MUC5AC mucin in tears and messenger ribonucleic acid levels in the conjunctival epithelium of patients with Sjögren syndrome are also significantly lower than those in normal individuals. ${ }^{8}$ On the other hand, the application of an ophthalmic solution containing mucin has been shown to accelerate healing of injured rabbit corneas, ${ }^{9}$ and accordingly it is thought that mucin secretagogues may provide therapeutic benefit in patients with dry eye. Several mucin secretagogues have been developed for patients with dry eye,${ }^{10}$ and diquafosol tetrasodium ophthalmic solution, a mucin secretagogue, has been in use for dry-eye patients in Japan since 2010.

Gefarnate is used to treat gastric ulcers in Japan. It is known to exert a protective effect against damage to the gastric epithelium by increasing gastric mucin secretion. ${ }^{11-13}$ There is also evidence that gefarnate stimulates in vitro secretion of mucin-like glycoprotein in cultured rat corneas. ${ }^{14}$ It has also been reported that gefarnate ophthalmic eye drops increase periodic acid Schiff(PAS)-positive cell density in normal rabbit conjunctiva, ${ }^{15}$ as well as alkali-injured conjunctiva in rabbits and monkeys, ${ }^{16,17}$ and ameliorates corneal damage due to desiccation in rabbits. ${ }^{14}$ However, the effects of gefarnate on secretion of mucin-like glycoprotein in conjunctiva and on corneal damage in dry-eye models have not been examined yet.

In this investigation, we examined the effect of gefarnate on the secretion of mucin-like glycoprotein in conjunctival tissue isolated from rabbits. We also investigated the effect of gefarnate ointment on rose bengal permeability in the cornea in a rabbit dry-eye model and corneal fluorescein staining score in a cat dry-eye model.

\section{Materials and methods}

\section{Animals}

Experiments were carried out in accordance with the Association for Research in Vision and Ophthalmology statement for the Use of Animals in Ophthalmic and Vision Research, and were approved by the Institutional Animal Care and Use Committee of Santen Pharmaceutical Co, Ltd.

Male Japanese white rabbits (1.8-2.4 kg body weight; Kitayama Labes, Ina, Nagano, Japan) and male domestic shorthair cats, aged 26-30 weeks (Liberty Research Inc, Waverly, NY, USA) were kept under standard pathogen-free conditions at $23^{\circ} \mathrm{C} \pm 5^{\circ} \mathrm{C}, 50 \% \pm 20 \%$ humidity, and with 12 hours of light and 12 hours of dark. The rabbits were fed approximately
$130 \mathrm{~g}$ of food per day and the cats approximately $90 \mathrm{~g}$ food per day, and both were given access to water ad libitum.

\section{Reagents}

Gefarnate was purchased from Kuraray Co, Ltd (Kurashiki, Okayama, Japan). Gefarnate ophthalmic ointments and vehicle were prepared by Santen Pharmaceutical Co, Ltd (Osaka, Japan). White petrolatum and liquid paraffin mixture was used as a vehicle.

\section{Isolation and incubation of rabbit conjunctival tissue}

Two rabbits were sacrificed under anesthesia with intramuscular ketamine and xylazine, and bulbar conjunctival tissue was excised with a $4 \mathrm{~mm}$ trephine (Biopsy Punch; Kai Medical, Gifu, Japan). The tissue was washed in normal bicarbonated Ringer's solution (111.5 mM NaCl, $4.8 \mathrm{mM} \mathrm{KCl}, 0.75 \mathrm{mM} \mathrm{NaH} \mathrm{PO}_{4}, 29.2 \mathrm{mM} \mathrm{NaHCO}$, $1.04 \mathrm{mM} \mathrm{CaCl}_{2} \cdot 2 \mathrm{H}_{2} \mathrm{O}, 0.74 \mathrm{mM} \mathrm{MgCl} \cdot 6 \mathrm{H}_{2} \mathrm{O}$, and $5.0 \mathrm{mM}$ $\mathrm{D}$-glucose) and then incubated in $1 \mathrm{~mL}$ of the same solution containing gefarnate for 24 hours at $37^{\circ} \mathrm{C}$ under a humidified atmosphere of $5 \% \mathrm{CO}_{2}$ and $95 \%$ air.

\section{Enzyme-linked lectin assay (ELLA) with wheat germ agglutinin (WGA)}

The secretion of mucin-like glycoprotein was measured using ELLA with WGA according to the method of TakaokaShichijo et al. ${ }^{18}$ Wells of a 96-well plate were coated overnight at $40^{\circ} \mathrm{C}$ with either the supernatants from incubations of conjunctival tissue or with bovine submaxillary gland mucin (Sigma-Aldrich, St Louis, MO, USA), followed by washing with $0.05 \%$ Tween 20 in Tris-buffered saline and incubation for 1 hour at room temperature (RT) with the same solution containing 3\% bovine serum albumin (blocking buffer). After incubation for 1 hour at RT with biotinylated WGA (Vector Laboratories, Inc, Burlingame, CA, USA) at a dilution of 1:1000 in blocking buffer, the wells were washed and incubated for 1 hour at RT with streptavidin-conjugated horseradish peroxidase (Dako, Glostrup, Denmark) at a dilution of 1:1000 in blocking buffer. The wells were then washed and streptavidin-horseradish peroxidase detected with tetramethyl benzidine solution. The reaction was stopped by the addition of $0.5 \mathrm{M} \mathrm{H}_{2} \mathrm{SO}_{4}$, and the absorbance at $450 \mathrm{~nm}$ of each well was determined using a microplate reader (Model 3550; Bio-Rad Laboratories, Hercules, CA, USA). A standard curve for bovine submaxillary gland mucin was calibrated using Kaleida Graph version 3.09a software (Hulinks Inc, Tokyo, Japan). 


\section{Creation of a rabbit dry-eye model}

Forty rabbits were anesthetized with intramuscular ketamine and xylazine, followed by instillation of oxybuprocaine (Benoxil ${ }^{\circledR}$ ophthalmic solution 0.4\%; Santen Pharmaceutical Co, Ltd) into the eyes. The lacrimal and Harderian glands, as well as the nictitating membrane in both eyes, were then removed using the modified Gilbard method. ${ }^{19}$ Eight weeks after surgery, the rabbits were administered eye ointments (approximately $30 \mu \mathrm{g}$ ) containing either the vehicle or $0.03 \%$, $0.1 \%, 0.3 \%, 1 \%$, or $3 \%$ gefarnate once daily for 1 week. Sham-operated rabbits only had the nictitating membrane removed without topical eye ointment application. The lacrimal glands, Hardarian glands, and the nictitating membrane of the operated control rabbits were removed without topical eye ointment application.

\section{Creation of a cat dry-eye model}

Twenty-five cats were anesthetized with a subcutaneous injection of xylazine and atropine sulfate, and an intramuscular injection of ketamine, followed by instillation of oxybuprocaine into the eyes. The lacrimal gland and nictitating membrane in the left eye were then removed using the modified McLaughlin method. ${ }^{20}$ The right eye was used as the normal eye. Five weeks after surgery, the cats received eye ointments containing either $50 \mu \mathrm{L}$ of vehicle or $1 \%$ or $3 \%$ gefarnate once daily for 4 weeks.

\section{Measurement of rose bengal permeability into the cornea in the rabbit dry-eye model}

The rabbits were anesthetized with intramuscular ketamine and xylazine about 24 hours after the last topical application, and their eyes were immersed and stained with a $1 \%$ rose bengal solution for 10 seconds. The rabbits were then sacrificed by an intravenous injection of an excessive amount of pentobarbital sodium. The eyes were then enucleated and the central area of the cornea was extracted using an $8 \mathrm{~mm}$-diameter trephine (Biopsy Punch). The dye in the cornea was then extracted in $2 \mathrm{M} \mathrm{NaOH}$ in the dark for 2 days. The optical density of the extracted solution was measured at $560 \mathrm{~nm}$ using a spectrometer (DU640; Beckman-Coulter, Inc, Brea, CA, USA).

\section{Corneal fluorescein staining in the cat dry-eye model}

The cats were anesthetized about 24 hours after the last topical application and their corneal epitheliums were stained with an instillation of $10 \mu \mathrm{L}$ of $1 \%$ fluorescein sodium solution.
After instillation, the excess fluorescein sodium solution was removed by washing with physiological saline. After washing, the corneal epithelium was photographed and examined with a slit lamp (SL-8Z; Topcon Medical Japan Co, Ltd, Tokyo, Japan) and the degree of damage was scored in a masked fashion. The criteria used for the score assessment was based on the method of Murakami and Nakamura. ${ }^{21}$ The cornea was divided transversally into three sections, and scores from 0 to 3 were given to each section according to the above mentioned criteria. For each section, a minimum score unit of 0.5 was assigned and the scores were summed to obtain the total score (maximum score of 9).

\section{Statistical analyses}

The data from two groups were analyzed using Student's $t$-test, whereas data from multiple groups were analyzed using Dunnett's multiple comparison test. $P<0.05$ was considered statistically significant.

\section{Results}

\section{Stimulation of mucin-like glycoprotein secretion from isolated rabbit conjunctival tissue by gefarnate}

We examined the effect of gefarnate on the secretion of mucin-like glycoprotein in isolated rabbit conjunctival tissue (Figure 1). Exposure to gefarnate at 0.002, 0.006, or $0.02 \mathrm{mg} / \mathrm{mL}$ for 24 hours increased the secretion of mucin-like glycoprotein in a dose-dependent manner. The secretion of mucin-like glycoprotein showed statistically significant differences at gefarnate concentrations of 0.006 and $0.02 \mathrm{mg} / \mathrm{mL}$ compared to the vehicle $(0 \mathrm{mg} / \mathrm{mL}$ of gefarnate)

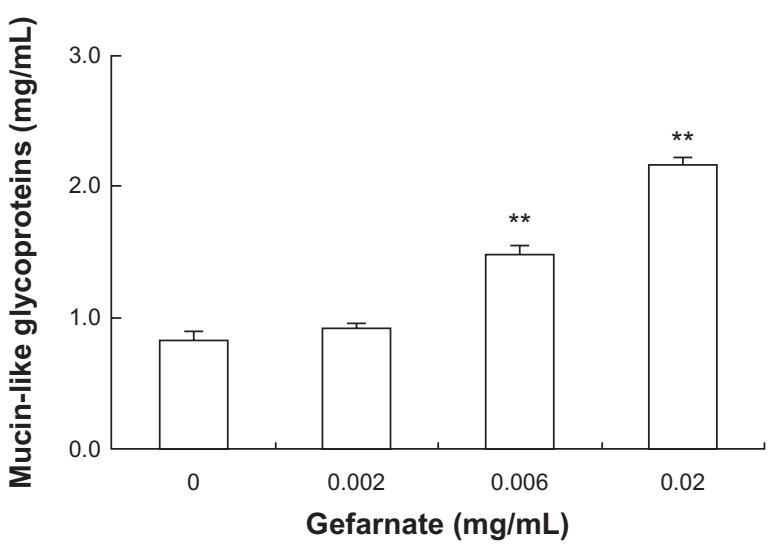

Figure I Effects of gefarnate on the secretion of mucin-like glycoproteins in rabbit bulbar conjunctival tissue.

Notes: Tissue was incubated for 24 hours with gefarnate. $* * P<0.01$ versus $0 \mathrm{mg} / \mathrm{mL}$ gefarnate (Dunnett's multiple comparison test). Each value represents the mean \pm standard error ( $n=4$ tissues). 


\section{Effect of gefarnate ointment on rose bengal permeability in the cornea in the rabbit dry-eye model}

Figure 2 shows that the permeability of rose bengal in the cornea of controls (operated animal without ophthalmic ointment application) significantly increased compared to that in the sham-operated animals. To determine whether gefarnate mitigated this increase in a dose-dependent manner, gefarnate $(0.03 \%-3 \%)$ and vehicle $(0 \%)$ ointments were applied topically once daily for 1 week. Compared to vehicle application, gefarnate application caused a dose-dependent decrease in rose bengal permeability in the cornea from $0.03 \%$ to $0.3 \%$, with permeability being significantly different at concentrations of $\geq 0.3 \%$. At gefarnate concentration of $\geq 0.3 \%$, the corneal permeability of rose bengal was decreased to the same level observed in sham-operated animals and reached a plateau. On the other hand, the vehicle had no effect on rose bengal permeability, with no significant differences observed compared to the controls.

\section{Effect of gefarnate ointment on fluorescein staining in the cat dry-eye model}

Figure 3 shows photographs of cat cornea stained by fluorescein sodium solution. Whereas normal cornea showed sparse and localized staining (Figure 3A), cornea without a lacrimal gland and nictitating membrane was stained heavily (Figure 3B). Applications of $1 \%$ or $3 \%$ gefarnate ointment once daily for 4 weeks to operated cornea weakened corneal fluorescein staining (Figure 3D and E) compared to that observed with the vehicle application (Figure 3C). Figure 4 shows the change in corneal fluorescein staining scores in the cat model after 4 weeks of repeated once daily instillation of $1 \%$ and $3 \%$ gefarnate ointment or the vehicle. The fluorescein staining score of the controls (operated animal without ophthalmic ointment application) significantly increased in comparison to that of normal eyes. Significant differences in the score were not observed between the groups (excluding normal eyes) prior to the start of instillation. Four weeks after instillation, the $1 \%$ and $3 \%$ gefarnate ointment groups had lower scores than the vehicle-treated group, with the score being significantly different at a gefarnate concentration of $3 \%$. In addition, no significant differences in scores were observed between the control group (operated eye without ophthalmic ointment application) and the group treated with vehicle after lacrimal gland removal. Accordingly, the effect of the vehicle was considered to be negligible.

\section{Discussion}

Gefarnate has been reported to increase the secretion of mucin-like glycoprotein from rat corneal epithelial cells in vitro, ${ }^{14}$ and to increase PAS-positive cell density in normal rabbit conjunctiva in vivo, as well as alkali-injured conjunctiva in rabbits and monkeys. ${ }^{15-17}$ We therefore examined whether gefarnate stimulated the secretion of mucin-like glycoprotein in rabbit conjunctiva. Our results showed that exposure of conjunctival tissue to gefarnate resulted in a concentration-dependent increase in the secretion of mucin-like glycoprotein. It has been demonstrated that the ELLA method using a WGA lectin detects mucin-like glycoprotein $>200 \mathrm{kDa}$ in rabbit conjunctival goblet cells. ${ }^{18}$ This indicates that gefarnate

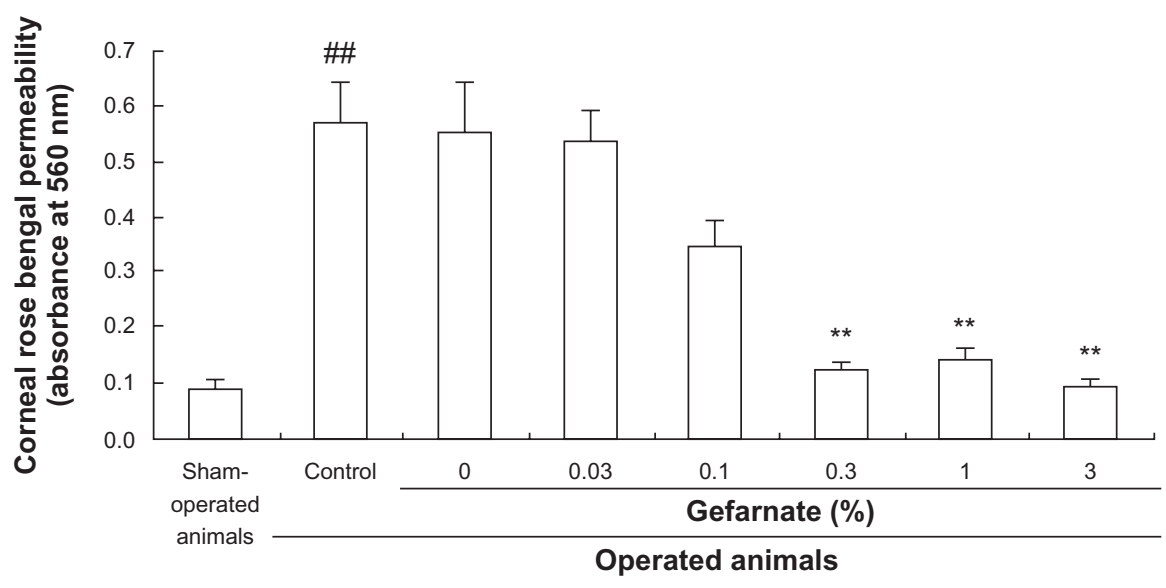

Figure 2 Effects of gefarnate ointment application on rose bengal staining in the rabbit dry-eye model.

Notes: Administration of gefarnate ointment began 8 weeks after removal of the lacrimal and Harderian glands, as well as after removal of the nictitating membrane. The ointment was applied once daily for I week at concentrations of $0 \%, 0.03 \%, 0.1 \%, 0.3 \%, 1 \%$, or $3 \%$. $P<0.0$ I versus sham-operated controls (Student's $t$-test); $* * p<0.0$ I versus $0 \%$ gefarnate (Dunnett's multiple comparison test). Each value represents the mean \pm standard error $(\mathrm{n}=10$ eyes). Control: disease control (no application). 

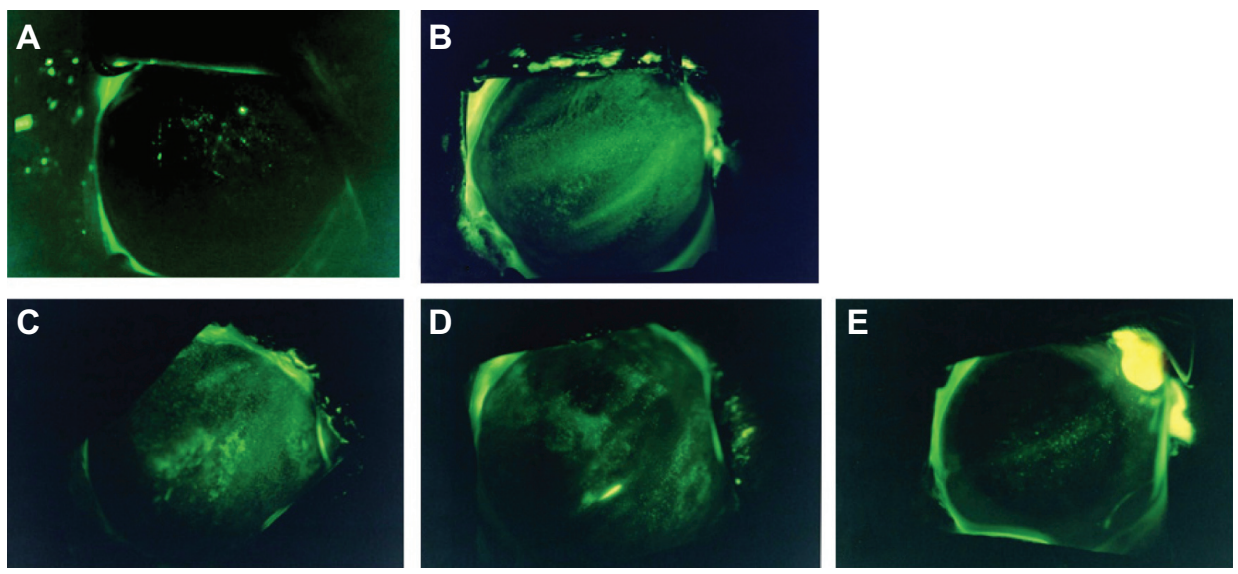

Figure 3 Representative photographs of fluorescein-stained corneas before and after application of gefarnate ointment for 4 weeks in the cat dry-eye model.(A) Normal cornea; (B) operated cornea before application; (C) cornea applied with vehicle; (D) cornea applied with $1 \%$ gefarnate; (E) cornea applied with $3 \%$ gefarnate.

stimulates mucin-like glycoprotein secretion not only in the cornea, ${ }^{14}$ but also in the conjunctiva containing goblet cells. The mechanisms of this stimulatory effect of gefarnate on mucin-like glycoprotein secretion on the ocular surface have not yet been established, although studies on gastritis and gastric ulcers have shown that gefarnate stimulates mucus secretion and synthesis of prostaglandin $\mathrm{E}_{2}\left(\mathrm{PGE}_{2}\right)$, which protects the mucosa. ${ }^{12}$ In addition, $\mathrm{PGE}_{2}$ induced MUC5AC gene expression and increased the amount of MUC5AC mucin in human nasal epithelial cells, ${ }^{22}$ and it stimulated the growth of colon cells. ${ }^{23}$ Both these effects of gefarnate may also stimulate the secretion of mucin-like glycoprotein in the cornea and conjunctiva and increase the PAS-positive cell density. The mechanisms of gefarnate on active mucin

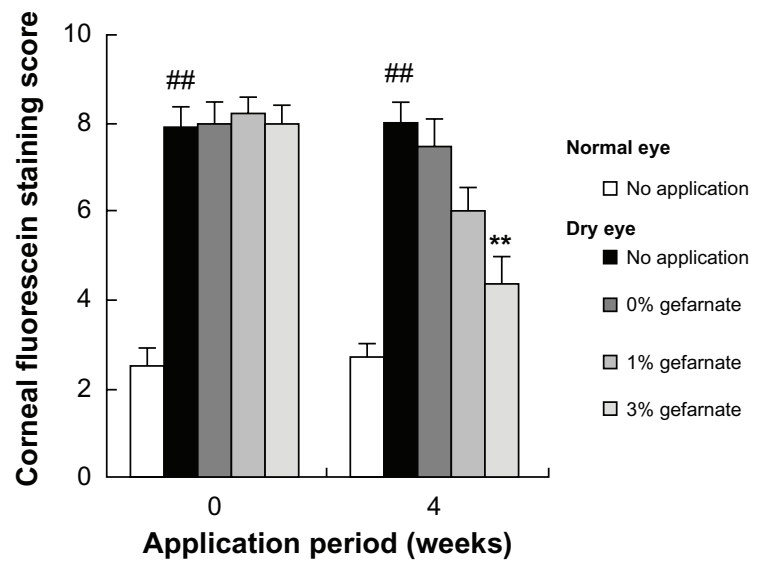

Figure 4 Effects of application of gefarnate ointment on fluorescein staining in the cat dry-eye model.

Notes: Administration of gefarnate ointment began 5 weeks after removal of the lacrimal gland and the nictitating membrane. The ointment was applied once daily for 4 weeks at concentrations of $0 \%, 1 \%$, or $3 \%$. ${ }^{\# P}<0.0$ l versus normal (Student's $t$-test). $* * P<0.0$ I versus $0 \%$ gefarnate (Dunnett's multiple comparison test). Each value represents the mean \pm standard error $(n=5$ eyes). secretion are thought to be mediated by exocytosis induced by $\mathrm{PGE}_{2}$ and by the stimulation of conjunctival goblet cell proliferation. It has also been proposed that the mechanism of mucin secretion by the conjunctiva may be associated with intracellular $\mathrm{Ca}^{2+}$ concentration and the epidermal growth factor signaling pathway. ${ }^{24}$ Some drugs with mucin secretion activity have been developed for the treatment of dry eye. In 2010, diquafosol tetrasodium ophthalmic solution was launched in Japan for the treatment of dry eye. This drug is a P2 $\mathrm{Y}_{2}$ agonist that activates mucin secretion by the intracellular calcium pathway. ${ }^{18}$ OPC-23759, also known as rebamipide, has been used as a gastroprotective drug by increasing gastric mucus secretion for the treatment of mucosa lesions in acute and chronic gastritis. ${ }^{25}$ It has been reported that rebamipide may also increase the proliferation of conjunctival goblet cells because of the effects of the epidermal growth factor receptor. ${ }^{26}$ Gefarnate has been used for a long time as an antigastric ulcer drug. Although there are some papers on gefarnate, the mechanism of action of gefarnate on the improvement of gastric ulcers in detail is still unknown. ${ }^{1-13}$ Based on our previous reports, ${ }^{14-17}$ we speculate that the mechanism of action of gefarnate on improving ocular surface damage is as follows. Gefarnate stimulates not only mucin secretion in the cornea and conjunctiva, but also stimulates the proliferation of goblet cells in the conjunctiva directly or indirectly. The mucins secreted by gefarnate cover the ocular surface and increase tear stability. As a result, gefarnate improves the ocular surface damage that occurs with dry eye. As far as we know in the literature, there are no reports to show antiinflammatory effects by gefarnate on the ocular surface. Further investigations are necessary to clarify these mechanisms of gefarnate on the ocular surface. 
Gilbard et $\mathrm{al}^{19}$ reported that the rabbit dry-eye model was created by removing the nictitating membrane and Harderian gland, and by closing the lacrimal gland excretory duct. Although this dry-eye model is associated with hyperosmolar tears and a decrease in goblet cell density, the Schirmer test and slit-lamp test results remain normal. ${ }^{19}$ In our preliminary study, we also showed no difference in the Schirmer test or corneal fluorescein staining score between the normal and operated groups (data not shown). A feature of this model is that tear volume is normal; however, tear quality is abnormal. Both the features in this dry-eye model - hyperosmolar tears and decreased goblet cell density - are seen in patients with dry eyes..$^{6-8,27}$ This model is therefore comparable to a mucin-deficient type of dry eye. We used rose bengal permeability in the cornea as an index of the efficacy of repeated gefarnate applications and showed that this treatment suppressed permeability in this model. On the basis of this result, we consider that gefarnate ointment may improve corneal epithelial damage by activating mucin-like glycoprotein secretion in cases of mucin-deficient dry eye.

It has been reported that a cat dry-eye model can be created by removing the lacrimal gland and nictitating membrane. ${ }^{20}$ The Schirmer test value for this model has been reported to be close to $0 \mathrm{~mm} / \mathrm{minute}$. This model therefore has features of a tear-deficient type of dry eye. We evaluated corneal damage in this model using fluorescein staining score. The operated cornea showed heavy corneal staining with a high score, and therefore we considered this model to be useful for evaluating therapeutic effects in severe dry eye conditions. Application of gefarnate ointment for 4 weeks weakened corneal fluorescein staining and decreased the score in this model, indicating an improvement in corneal epithelial damage. This effect of gefarnate in a cat dry-eye model might be associated with not only increasing mucin secretion on the ocular surface, but also with stimulating corneal epithelial cell growth via $\mathrm{PGE}_{2 .}{ }^{12,23}$

In conclusion, we demonstrated that gefarnate stimulated the secretion of mucin-like glycoprotein in isolated rabbit conjunctival tissue, and that gefarnate ointment ameliorated corneal epithelial damage in two animal dry-eye models. These results suggest that gefarnate may be used in the treatment of both mucin-deficient and tear-deficient dry eye.

\section{Acknowledgment}

The authors thank Takashi Nagano for his advice and support in the preparation of this manuscript.

\section{Disclosure}

All authors are employees of Santen Pharmaceutical Co, Ltd. The authors report no other conflicts of interest in this work.

\section{References}

1. Holly FJ, Lemp MA. Tear physiology and dry eyes. Surv Ophthalmol. 1977;22(2):69-87.

2. Watanabe H. Significance of mucin on the ocular surface. Cornea. 2002;21(Suppl 1):S17-S22.

3. Holly FJ, Lemp MA. Wettability and wetting of corneal epithelium. Exp Eye Res. 1971;11(2):239-250.

4. Kardon R, Price RE, Julian J, et al. Bacterial conjunctivitis in Muc1 mice. Invest Ophthalmol Vis Sci. 1999;40(7):1328-1335.

5. The definition and classification of dry eye disease: report of the Definition and Classification Subcommittee of the International Dry Eye WorkShop (2007). Ocul Surf. 2007;5(2):75-92.

6. Nelson JD, Wright JC. Conjunctival goblet cell densities in ocular surface disease. Arch Ophthalmol. 1984;102(7):1049-1051.

7. Pisella PJ, Brignole F, Debbasch C, et al. Flow cytometric analysis of conjunctival epithelium in ocular rosacea and keratoconjunctivitis sicca. Ophthalmology. 2000;107(10):1841-1849.

8. Argüeso P, Balaram M, Spurr-Michaud S, Keutmann HT, Dana MR, Gipson IK. Decreased levels of the goblet cell mucin MUC5AC in tears of patients with Sjögren syndrome. Invest Ophthalmol Vis Sci. 2002;43(4):1004-1011.

9. Shigemitsu T, Shimizu Y, Majima Y. Effects of mucin ophthalmic solution on epithelial wound healing in rabbit cornea. Ophthalmic Res. 1997;29(2):61-66.

10. Peral A, Domíngues-Godínez CO, Carracedo G, Pintor J. Therapeutic targets in dry eye syndrome. Drug News Perspect. 2008;21(3): $166-176$.

11. Bersimbaev RI, Tairov MM, Salganik RI. Biochemical mechanisms of regulation of mucus secretion by prostaglandin E2 in rat gastric mucosa. Eur J Phrmacol. 1985;115(2-3):259-266.

12. Kobayashi K, Arakawa T, Nakamura H, et al. Effect of gefarnate on endogenous prostacyclin, prostaglandin E2 and thromboxane in waterimmersed rats. Tohoku J Exp Med. 1983;140(2):181-185.

13. Truelove SC, Rocca M. Treatment of chronic gastric ulcer with gefarnate: a long-term controlled therapeutic trial. Curr Med Res Opin. 1976;4(3):218-222.

14. Nakamura M, Endo K, Nakata K, Hamano T. Gefarnate stimulates secretion of mucin-like glycoproteins by corneal epithelium in vitro and protects corneal epithelium from desiccation in vivo. Exp Eye Res. 1997;65(4):569-574.

15. Nakamura M, Endo K, Nakata K, Hamano T. Gefarnate increases PAS positive cell density in rabbit conjunctiva. $\mathrm{Br} J$ Ophthalmol. 1998;82(11):1320-1323.

16. Toshida H, Nakata K, Hamano T, Nakamura M, Nguyen D, Beuerman R. Gefarnate stimulates goblet cell repopulation following an experimental wound to the tarsal conjunctiva in the dry eye rabbit. Adv Exp Med Biol. 2002;506(Pt A):353-357.

17. Toshida H, Nakata K, Hamano T, Nakamura M, Nguyen D, Beuerman RW. Effect of gefarnate on the ocular surface in squirrel monkeys. Cornea. 2002;21(3):292-299.

18. Takaoka-Shichijo Y, Shinomiya K, Katsuta O, Nakamura M. [Stimulatory action of diquafosol tetrasodium on mucin-like glycoprotein secretion in rabbit conjunctival tissues]. Journal of the Eye. 2011;28(4):543-548. Japanese.

19. Gilbard JP, Rossi SR, Gray KL. A new rabbit model for keratoconjunctivitis sicca. Invest Ophthalmol Vis Sci. 1987;28(2):225-228.

20. McLaughlin SA, Brightman AH 2nd, Helper LC, Primm ND, Brown MG, Greeley S. Effect of removal of lacrimal and third eyelid glands on Schirmer tear test results in cats. J Am Vet Med Assoc. 1988;193(7):820-822. 
21. Murakami T, Nakamura M. [Combined effects of Hyaluronan and artificial tear solutions in rat dry eye model]. Journal of the Eye. 2004;21(1):87-90. Japanese.

22. Kook Kim J, Hoon Kim C, Kim K, Jong Jang H, Jik Kim H, Yoon JH. Effects of prostaglandin E(2) on gel-forming mucin secretion in normal human nasal epithelial cells. Acta Otolaryngol. 2006;126(2):174-179.

23. Sheng H, Shao J, Washington MK, DuBois RN. Prostaglandin E2 increases growth and motility of colorectal carcinoma cells. J Biol Chem. 2001;276(21):18075-18081.

24. Dartt DA. Regulation of mucin and fluid secretion by conjunctival epithelial cells. Prog Retin Eye Res. 2002;21(6):555-576.
25. Iijima K, Ichikawa T, Okada S, et al. Rebamipide, a cytoprotective drug, increases gastric mucus secretion in human: evaluations with endoscopic gastrin test. Dig Dis Sci. 2009;54(7):1500-1507.

26. Ríos JD, Shatos M, Urashima H, Tran H, Dartt DA. OPC-12759 increases proliferation of cultured rat conjunctival goblet cells. Cornea. 2006;25(5):573-581.

27. Lemp MA, Bron AJ, Baudouin C, et al. Tear osmolarity in the diagnosis and management of dry eye disease. Am J Ophthalmol. 2011;151(5) 792-798.
Clinical Ophthalmology

\section{Publish your work in this journal}

Clinical Ophthalmology is an international, peer-reviewed journal covering all subspecialties within ophthalmology. Key topics include: Optometry; Visual science; Pharmacology and drug therapy in eye diseases; Basic Sciences; Primary and Secondary eye care; Patien Safety and Quality of Care Improvements. This journal is indexed on

Submit your manuscript here: http://www.dovepress.com/clinical-ophthalmology-journal

\section{Dovepress}

PubMed Central and CAS, and is the official journal of The Society of Clinical Ophthalmology (SCO). The manuscript management system is completely online and includes a very quick and fair peer-review system, which is all easy to use. Visit http://www.dovepress.com/ testimonials.php to read real quotes from published authors. 